\title{
The Effect of Scratch Program Based on Local Wisdom For Students' English Speaking Skill at SMP N 4 Percut
}

\author{
$1^{\text {st }}$ Sumarsih $^{1}, 2^{\text {nd }}$ Rosmawati Harahap ${ }^{2}, 3^{\text {rd }}$ Safrida Lubis $^{3}, 4^{\text {th }}$ Asrita Sari ${ }^{4}$ \\ \{prof.sumarsih@gmail.com ${ }^{1}$, rosmawatihrp@gmail.com ${ }^{2}$, safridalubis61@gmail.com ${ }^{3}$ \} \\ Universitas Negeri Medan, Indonesia ${ }^{1,2,3,4}$
}

\begin{abstract}
. 21st century learning requires teachers to be able in creating creative and innovative learning. One of them is by utilizing technological advances through programs that have been designed in accordance with the current developments such as scratch program. Thus, the aim of the study was to develop and implement scratch program based on North Sumatera local wisdom in enhancing students' motivation to improve English speaking skill at SMP N 4 Percut. Research and development was conducted in this study. There were some steps conducted such as, preliminary, developing, and evaluating. 30 students of seventh, eighth, and ninth grade were the subject of the study. The sample was selected randomly. The techniques of collecting data were observation, interview and questionnaire. Furthermore, the data were analyzed by using descriptive qualitative and quantitative analysis. The result of the study showed that scratch program based on local wisdom gave positive impact toward students' motivation in improving English speaking skill. It was also proven through the result of media development validation from the experts namely the average percentage $95 \%$ categorized excellent. In addition, the scratch program based on local wisdom was an appropriate media in teaching genres at SMP N 4 Percut contextually.
\end{abstract}

Keywords: Scratch Program, Speaking Skill, Genres, Research and Development.

\section{Introduction}

Developments in the twenty-first century require all components be able to compete with the times, which continue to provide a variety of obstacles that each element must be able to overcome in order to survive and not be left behind by the times. One of them is the issue of education. Education is inextricably linked to the process of learning. Learning is a set of activities designed with the goal of assisting pupils in their learning. Furthermore, learning is a learning process designed by teachers to foster creative thinking in pupils, which can help them enhance their thinking skills and their ability to construct new knowledge. Learning is a process of interaction between students and educators, as well as learning resources, in a learning environment [1].

Learning is a system or learning process for learners that is organized, implemented, and evaluated systematically in order for learners to attain learning goals [2].

21 st century learning is simply defined as learning that teaches students 21 st century skills, namely 4C including : (1) Communication (2) Collaboration, (3) Critical Thinking and problem solving, dan (4) Creative and Innovative. Students must master 4C skillss in order to 
progress in this course. The function of education and learning, which is applied in schools through innovative learning such as the use of technology and mastery of program languages as the demands of the twenty-first century, cannot be divorced from obtaining these talents. It demands pupils to learn the many programs given by the advancement of technology, either directly or indirectly. As a result, today's learning must be able to combine and communicate online and offline learning, as well as take advantage of technological capabilities. This is inextricably linked to the role of a teacher as an educator, whose primary responsibility is to educate, teach, guide, lead, train, assess, and evaluate pupils [3].

In 21 st century learning, teachers and students collaborate to apply learning by incorporating technology into the classroom [4]. As a result, students will be taught to use their HOTS (Higher Order Thinking Skill) thinking skills to develop their critical thinking skills and solve problems (problem solving) when confronted with any challenge in the classroom. Furthermore, learning that is designed innovatively and creatively becomes a solution to difficulties in the classroom, such as students' lack of interest and motivation to learn. In education, creativity is just as vital as reading, and we should treat it as such. Programming abilities are the foundation for mastering robotic applications, and coding is the foundation for mastering robotic applications. Algorithms are also the foundation of programming. All of these talents are built on the foundation of problem-solving abilities. Learning programming skills is challenging since it is difficult to acquire competence in problem-solving methodologies and constructing solutions efficiently. Visual programming languages like Alice code, code.ogr, and Scratch have helped bring it to life in recent years. As a result of these applications, computer programming has become easier and more understandable for everyone. Computational thinking (computational thinking) refers to the knowledge, abilities, and attitudes required to use computers as a tool for problem solving in everyday life. Computational thinking is a way of looking at human behavior that focuses on problem solving, systems design, and basic computer science concepts.

However, based on the findings of the observations, 21st century learning is not being fulfilled to its full potential, which has an impact on student learning outcomes. One of them is English learning. There are four basic abilities in English that must be acquired. One of them is reading skill. Mastering reading skill is a receptive skill that allows students to comprehend material; this ability is referred to as reading comprehension. The text genre is one of the texts that students must master.

Procedural text, description, narrative, recount, explanation, exposition, discussion, and review are all sorts of text [5].

The speaking skill of students was still rather low, according to preliminary data received from SMP N 4 Percut. The students' learning outcomes in genre-based Speaking are still well below the Minimum Graduation Criteria, demonstrating this (KKM). The English KKM score is 70 in this case. This was caused by pupils' lack of enthusiasm and desire in learning genrebased. The students become bored and disinterested in learning as a result of the online and monotonous learning procedure. In reality, according to the 2013 curriculum as the school curriculum, learning should be based on student-centered learning.

Furthermore, student learning results are influenced by teachers who have not maximized their role in 21 st century learning by establishing innovative and creative learning. According to the observations, English teachers continue to employ traditional methods. When teaching genre- based Speaking and connecting it with technological changes, teachers still infrequently employ learning media. Media is a way of sending or delivering communications, and in the context of learning, it is utilized to convey content to recipients in order to achieve effective instruction [6]. 
As a result, the authors were interested in doing research to see if using the scratch application helped the students to improve their genre-based speaking skills. Where the genre's text will be modified to North Sumatra's local wisdom. This was to support contextual learning and the use of programming languages in the classroom (coding). As a result, the expectations of twenty-first-century learning will be addressed. Scratch is a visual programming language that may be used to create a variety of works such as tales, games, animations, music, art, and presentations using a drag-and-drop interface. Scratch is a simple programming tool that can be used to learn English. As a result, the scratch program is a program that meets the needs of students and teachers in meeting the objectives of $21 \mathrm{st}$ century learning while also integrating technology and language advances to increase student engagement in the English learning process.

Thus, the purpose of this study was to develop and implement a local wisdom-based scratch program in improving the speaking skills of students at SMP N 4 Percut, Deli Serdang.

\section{Method}

A Research and Development design was used to construct a local wisdom-based scratch program to help students at SMP N 4 Percut improve their English speaking skills. This method is a research method that is used to create items and test their efficiency [7]. Research and development is a series of steps used to create a new product or improve an existing one, and it is accounted for in the budget [8].

Since the aim of the study was to develop and implement scratch program based on North Sumatera local wisdom in enhancing students' motivation to improve English speaking skill at SMP N 4 Percut. Research and development was conducted in this study. There were some steps conducted such as, preliminary, developing, and evaluating. 30 students of seventh, eighth, and ninth grade were the subject of the study. The sample was selected randomly. The techniques of collecting data were observation, interview and questionnaire. Furthermore, the data were analyzed by using descriptive qualitative and quantitative analysis.

\section{Results and Discussion}

The data of the study found showed that there were some obstacles faced by English teachers and students at SMP N 4 Percut such as, (1) lack of motivation in studying English particularly genre based; (2) the difficulties in mastering English genre texts since they were not taught contextually; (3) lack of confidence in delivering genre texts through speaking; (4) lack of media learning which was able to motivate the students in enhancing the learning's goal particularly in speaking skill; and (5) lack of interaction which made the students tend to be passive so that speaking skill could not improve properly.

Then, based on need analysis conducted, it was found that the teacher and students need a media which can support English learning particularly about genre texts at SMP N 4 Percut. The teacher and students need a media which can be used contextually so that the lessons can be easier to be comprehended and the students are more confident in speaking about genre texts for the students master the topic correctly. 
Therefore, the authors developed scratch program based on local wisdom for students' english speaking skill at SMP N 4 Percut. The program was designed through coding which can be shown in the figure below.

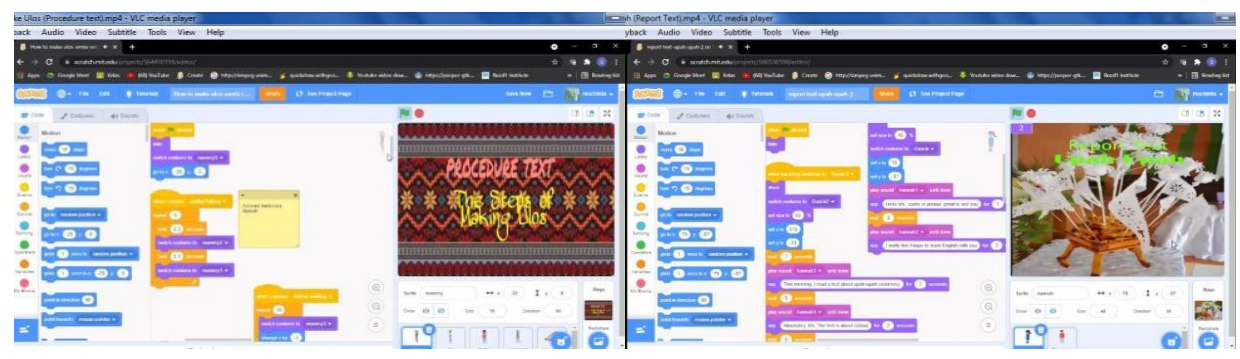

Fig. 1. The process of Coding.

The media can be used to teach genre texts which are studied in junior high school based on curriculum 13 namely, descriptive, narrative, recount, procedure, and report text. The media was designed by providing video based on North Sumatera local wisdom through scratch program. It encourage the students since the story and topics upheld are from North Sumatera and seldom to be found in the society. Thus, it also can add the knowledge teachers and students to enrich the information of local wisdom in North Sumatera which shows the diversity. In addition, the media used some topics relating some ethnics in North Sumatera such as, Bataknese and Melayuness. The figures below show the layout of scratch program which had been designed based on local wisdom of North Sumatera for speaking skill at SMP N 4 Percut.

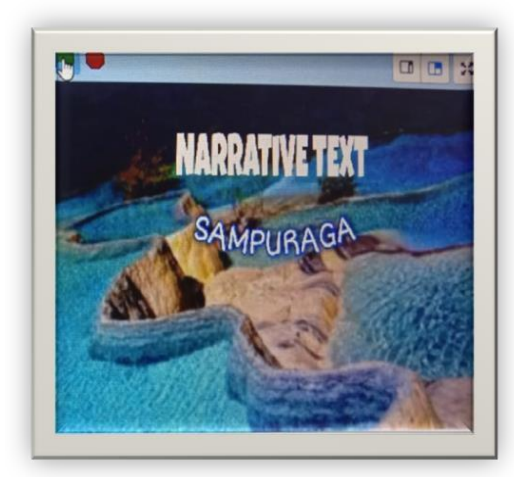

Fig. 2. The Cover of Media.

From the figure above, it is known that the genre text is narrative text and Sampuraga is the examples. 


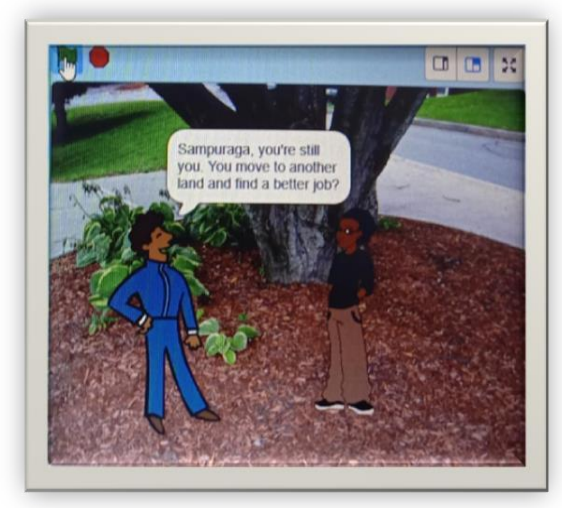

Fig. 3. The Content of Sampuraga Story.

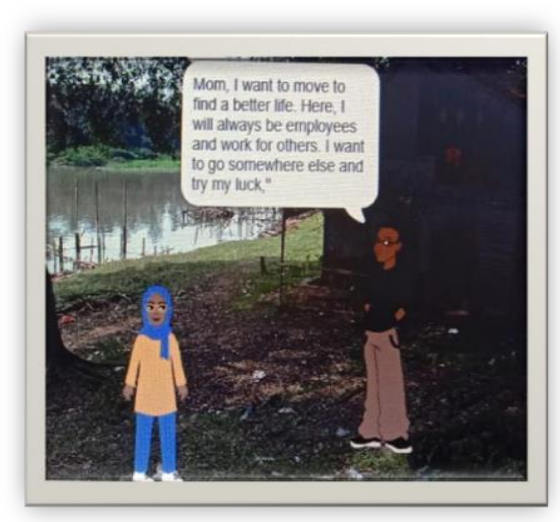

Fig. 4. The Dialogue of the Story.

The figure above shows an conversation about Sampuraga story. Since the text is narrative text, so the media was designed to show a role play. Thus, the students could imitate it.

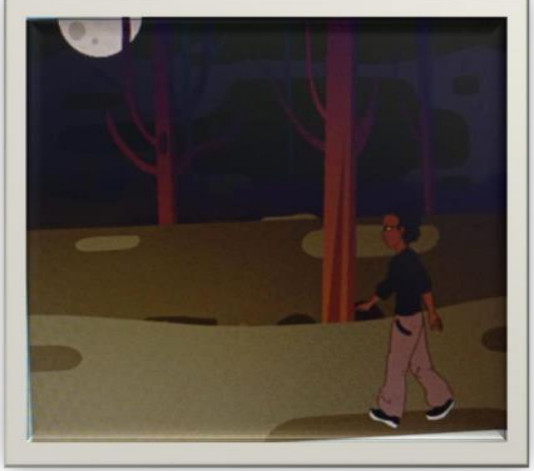

Fig. 5. The Story's Situation. 
The situation above would encourage to the students to get more the story's messages so that the students would be able to tell or play the role play relating to the narrative text itself.

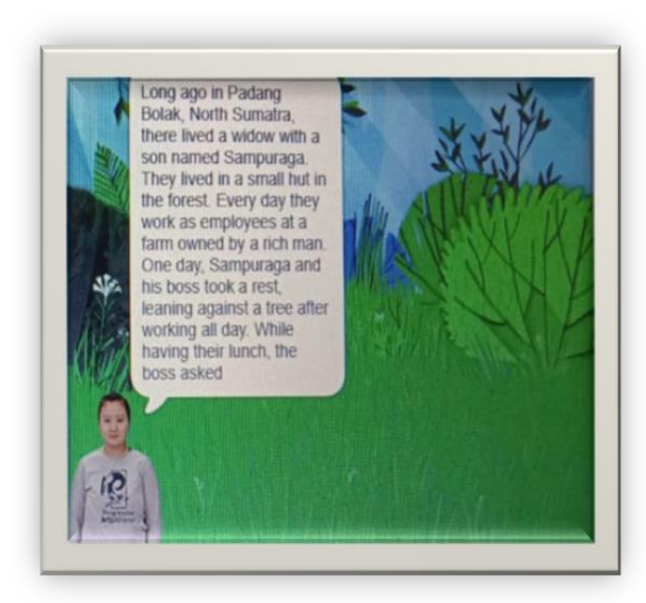

Fig. 6. Story Telling.

The media also was added by a narrator who made the students were able to pronounce those words. Since the skill improved was speaking skill. Thus, pronunciation is very necessary to be studied.

Furthermore, some experts had validated the media. The experts were an English and Literature department lecturer and two English teachers at SMP N 4 Percut. Based on the validation results, it was determined that the number of validation percentages was 95 percent, which was classified as excellent. After the media designed using the scratch software was validated and improved, it was used to teach students at SMP N 4 Percut about speaking based on genre texts. Its findings revealed that students' writing skills in relation to genres improved, indicating that the media was an effective medium for learning speaking at SMP N 4 Percut. It could be got based on questionnaire of media evaluation given to English teachers and the students at SMP N 4 Percut.

Additionally, scratch program use was also demonstrate to the teacher in order that the students will be able to design another media and the teacher will also be able in encouraging the students in improving the speaking as well as 4C skills namely, : (1) Communication (2) Collaboration, (3) Critical Thinking and problem solving, dan (4) Creative and Innovative. Not only that, through the use of media, it will answer the obstacles of 21 st century learning which must be faced in this era.

\section{Conclusion}

The aim of this study was to develop and implement a local wisdom-based scratch program in improving the speaking skills of students at SMP N 4 Percut, Deli Serdang. The data of the study found showed that there were some obstacles faced by English teachers and students at SMP N 4 Percut such as, (1) lack of motivation in studying English particularly genre based; (2) the difficulties in mastering English genre texts since they were not taught 
contextually; (3) lack of confidence in delivering genre texts through speaking; (4) lack of media learning which was able to motivate the students in enhancing the learning's goal particularly in speaking skill; and (5) lack of interaction which made the students tend to be passive so that speaking skill could not improve properly.

Therefore, scratch program was developed based on local wisdom of North Sumatera. some experts had validated the media. The experts were an English and Literature department lecturer and two English teachers at SMP N 4 Percut. Based on the validation results, it was determined that the number of validation percentages was 95 percent, which was classified as excellent. After the media designed using the scratch software was validated and improved, it was used to teach students at SMP N 4 Percut about speaking based on genre texts. Its findings revealed that students' speaking skills in relation to genres improved, indicating that the media was an effective medium for learning speaking at SMP N 4 Percut.

Additionally, by developing scratch program in motivating students to improve speaking skill is also an answer in facing 21 st centuries learning in this era.

\section{References}

[1] Law No. 20 of 2003 regulating the National Education System. Jakarta: Presiden Republik Indonesia; 2003.

[2] Komalasari K. Pembelajaran Kontekstual. Bandung: Refika Adiatama; 2013.

[3] Article 1 of Law No. 14 of 2005 on Teachers and Lecturers. Jakarta: Depdiknas; 2005.

[4] Larson LC. Digital Readers: The Next Chapter in E-Book Reading and Response. The Reading Teacher. 2010; 64(1):15-22.

[5] Pardiyono. Pasti Bisa! Teaching Genre-Based Writing. Yogyakarta: Andi Offset; 2007.

[6] Naz AA, Akbar RA. Use of Media for Effective Instruction its Importance: Some Consideration. J Elementary Educ A Publication of Deptt. of Elementary Education IER, University of the Punjab, Lahore - Pakistan. 2008; 18(1-2):35-40.

[7] Sugiyono. Metode Penelitian Kuantitatif, Kualitatif, dan R\&D. Bandung: CV Alfabeta; 2010.

[8] Trianto. Mendesain pembelajaran Kontekstual di Kelas. Surabaya: Cerdas Pustaka; 2008. 